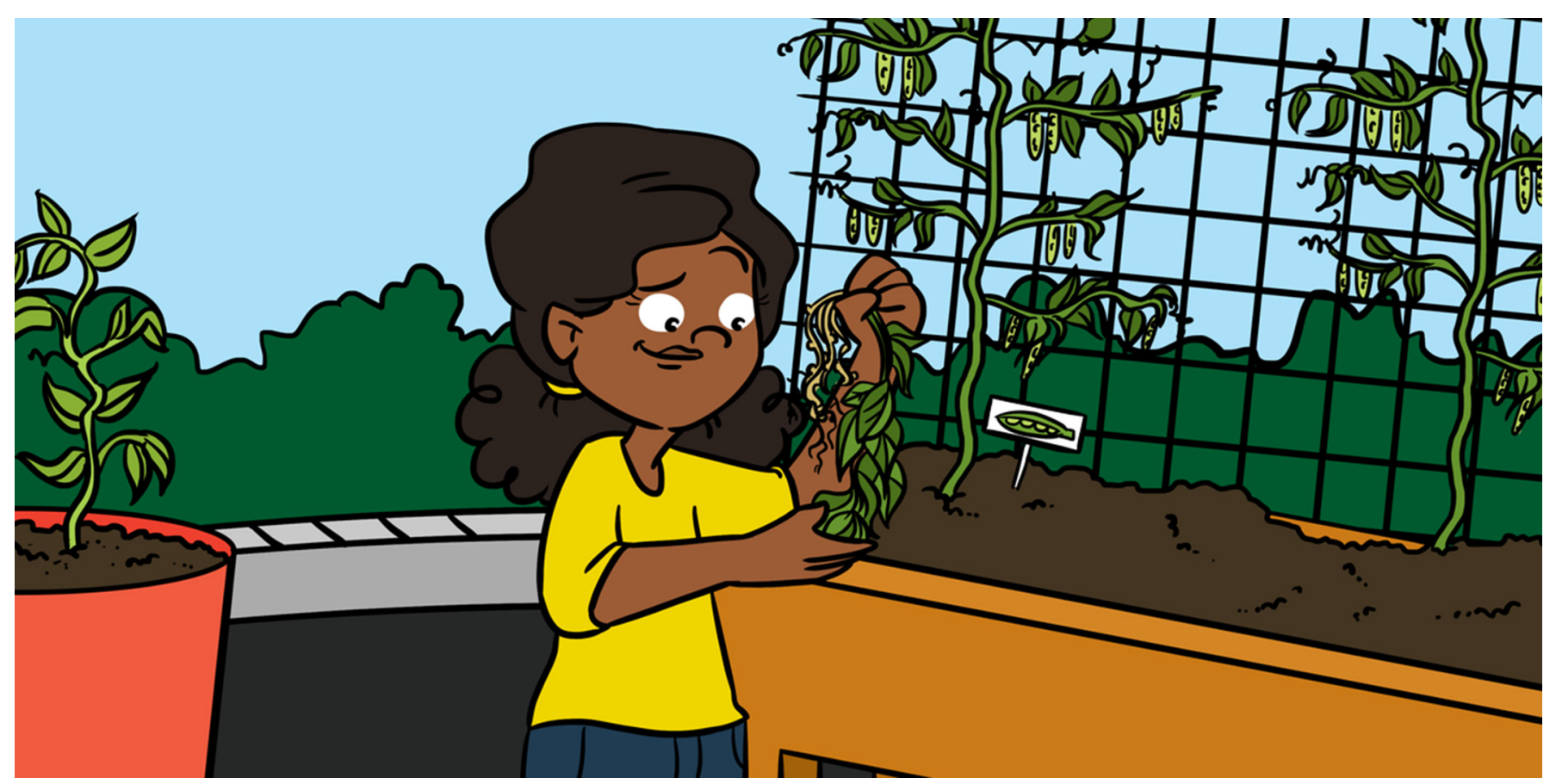

\title{
WHAT ARE THE SMALL LUMPS I SEE ON SOME PLANT ROOTS?
}

\section{Fede Berckx* and Katharina Pawlowski}

Department of Ecology, Environment and Plant Sciences, Stockholm University, Stockholm, Sweden

\section{YOUNG REVIEWERS:}

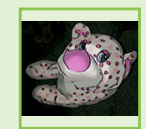

\section{ELLE}

AGE: 11

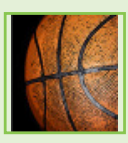

JACK

AGE: 13

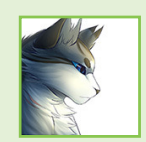

SIRI

AGE: 12

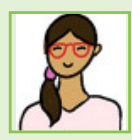

SOPHIA

AGE: 15

\section{NODULE}

A special organ formed on the roots of plants, in which certain bacteria can live and exchange nutrients with the plant.
Microorganisms, such as bacteria and fungi, can live together with plants in a tight relationship where they help each other to provide nutrients. Some groups of bacteria can turn nitrogen, an essential element, from a gas in the atmosphere into a form that plants can use. In return, plants provide carbon to the bacteria. This special relationship is called symbiosis. Researchers try to understand why some plants interact with these helpful bacteria and others do not. They do this by looking at how the symbiotic relationship was formed and how it evolved over a long period of time of several million years. If we can use symbiotic microorganisms to provide plants with nutrients instead of using fertilizers, we could reduce the negative effects caused by greenhouse gasses associated with their production.

\section{IT IS ALL ABOUT NITROGEN}

If you have ever dug up a clover plant you might have seen small, pink or yellow lumps on the plant's roots (Figure 1). These are structures-we call them nodules - that are made by the plant. Nodules 
Figure 1

Diversity of nodules on various plants. The plants are shown on the left and their nodules are shown on the right. (A) Coriaria sp. (tutu). (B) Discaria trinervis (chacay). (C) Pisum sativum (garden pea). Photo credit: F. Berckx.

\section{NITROGEN}

The most common chemical element in the atmosphere.
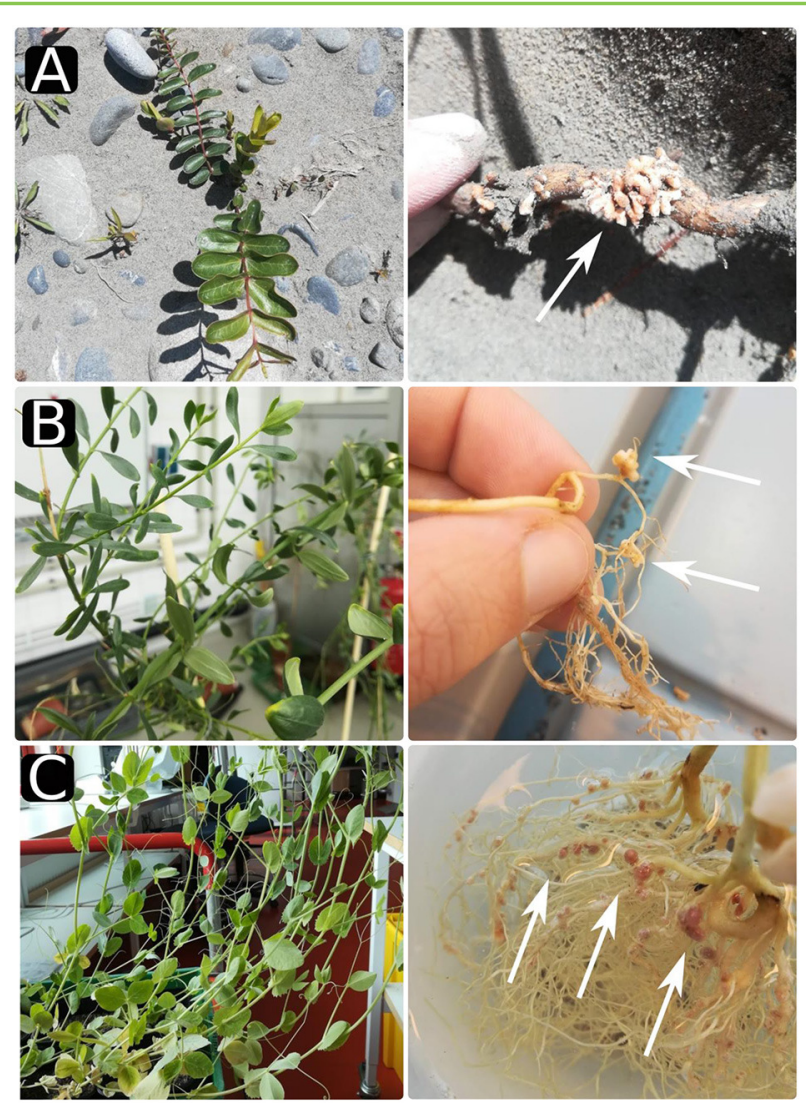

Figure 1

are essential for helping the plant get nitrogen from the atmosphere when there is not enough nitrogen present in the soil. Yes, structures of a plant found in the soil are important for getting nutrients from the atmosphere! Like humans and animals, plants need water and nutrients to grow. Like carbon, nitrogen is an important building block of any organism. It is the most common component in the atmosphere. Nitrogen gas makes up around $78 \%$ of the atmosphere. To compare, the oxygen we breathe makes up only $21 \%$ of the atmosphere. While humans and animals breathe in nitrogen gas, we cannot directly use the nitrogen in the air. So, we rely on food sources for getting our nitrogen supply. Getting enough nitrogen is usually not an issue for people or animals, but it can be a problem for plants, that do not eat other organisms.

So where do plants get their nitrogen from? Well, they use their roots to take up nitrogen from the soil. In modern agriculture, nitrogen and other nutrients are mostly supplied by man-made fertilizers. Nitrogen-containing fertilizer was invented roughly 100 years ago by two people: Fritz Haber and Carl Bosch. Both received the Nobel Prize for their work. Unfortunately, we are now learning about the negative effects on the environment by using this fertilizer. For instance, during the production, a lot of $\mathrm{CO}_{2}$ is released into the atmosphere. The fertilizers can also pollute aquatic ecosystems such 
Figure 2

After a volcanic eruption, the volcanic ash that covers the soil is low in nitrogen (N). Nodule-forming plants can settle in this harsh environment, and with the help of their bacterial friends, they can get nitrogen from the atmosphere. As the soil becomes richer in ammonia $\left(\mathrm{NH}_{3}\right)$, more plants can begin to grow in the area.

\section{MICROORGANISM}

Tiny organisms like bacteria, archaea and fungi, but also very small animals or algae which can only be seen with a microscope.

\section{NITROGEN-FIXING BACTERIA}

A type of bacteria that can take up nitrogen from the atmosphere and convert it into a form that plants can use, such as ammonia. Some archaea are also able to fix nitrogen.

\section{SYMBIOSIS}

A relationship between two organisms from different species live closely together and both profit from the relationship.

\section{LEGUME}

Plants that belong to the pea family, which also includes beans and clover. Most of them are symbiotic

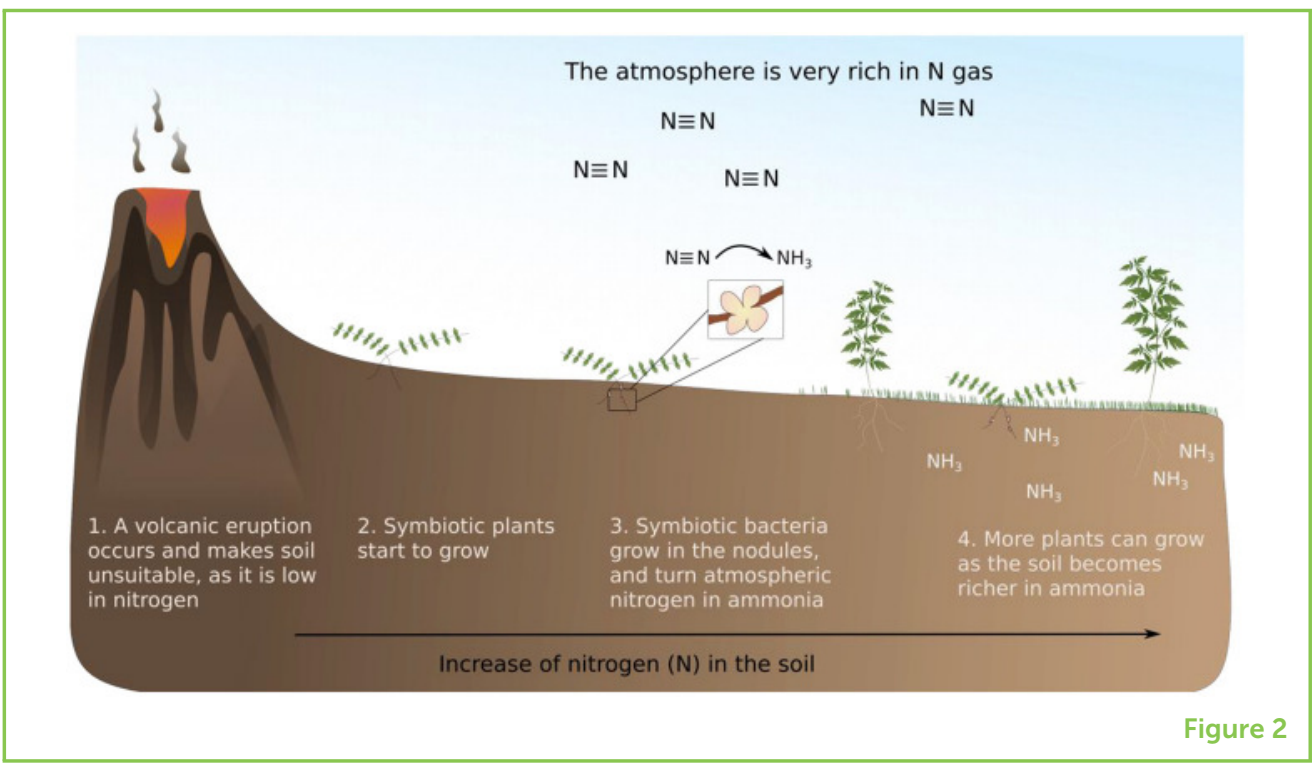

as lakes when too much nitrogen enters. Plants have been grown as crops for much longer than fertilizers have been in use. Not all plants are grown by farmers. So how do those plants get nitrogen? And, can we learn anything these plants to make agriculture more environmentally friendly?

\section{BACTERIA IN NODULES CAN HELP PLANTS GET NITROGEN}

The soil contains some nitrogen that is available to plants. Part of this nitrogen comes from decay of organisms, for example. Soil also contains a lot of microorganisms which are super small organisms like fungi, bacteria, or tiny animals like water bears. Certain bacteria in the soil, called diazotrophs, can turn nitrogen gas from the atmosphere into ammonia, which is a form of nitrogen that plants can use (Figure 2). This process is called nitrogen fixation, and the bacteria that can do it are called nitrogen-fixing bacteria. Some diazotrophs form a close relationship with plants through a process called root nodule symbiosis. Symbiosis means that two, or more, organisms live and interact with each other in a close relationship, in which both organisms profit. The plant forms nodules of various shapes, colors, and sizes on their roots (Figure 1). If we think about all plants that exist, only a small group is able to make nodules. The bacteria live inside the root nodules where they trade nutrients with the plants. The bacteria provide nitrogen and the plant provides sugars from photosynthesis. Not all plants can make nodules, so this type of symbiosis is restricted to only certain plants. For examples, clover, pea, bean, and peanut plants are all part of the same plant family which we call legumes [1]. But there are also some non-legume plants that can make root nodules [2]. 
Every plant that can make nodules shares a great-great-great grandparent who lived 100 million years ago. This means that they are all related to each other and that their ancestor could make nodules [3]. But since that time, many plants have lost the ability to make nodules. How do these plants get nitrogen? They must rely on nitrogen available in the soil. Plants that make nodules are often found in harsher environments, like on the edges of beaches, or they are the first plants to grow in the ash after a volcanic eruption. Thanks to their bacterial friends, they can grow in these harsh environments and, over time, make the soil richer in nitrogen. Enriching the soil with nitrogen benefits plants without nodules, which generally arrive later (Figure 2).

Symbiosis seems like a big advantage, so why did many plants lose this ability? This is puzzling to researchers. Some think that perhaps it was because of "cheaters" in the soil: bacteria that could pretend to be beneficial but did not provide enough nitrogen to plants. Also, since symbiosis requires energy, if the soil is already rich enough in nitrogen, it might be better for plants not to invest in symbiotic relationships.

\section{PLANTS AND BACTERIA USE CHEMICALS TO FIND EACH OTHER}

How do host plants and bacteria find each other? To communicate with other organisms, plants release chemicals into the soil. These chemicals tell bacteria which plants are growing nearby. If the plants are the right kind, the bacteria will release chemicals too, telling the plants that friendly nitrogen-fixing bacteria are nearby. In some cases, only specific types of bacteria will interact with certain plants, and the details of plant-bacteria communication are still not well-understood for some plants. Scientists do know that the way plants communicate with their friendly bacteria is very similar to the way plants communicate with certain types of fungi that also help plants to obtain nutrients like nitrogen and phosphorus [4]. Symbioses with these fungi are much more common than nodule symbiosis. Researchers estimate that the symbiotic relationship with fungi emerged 500 million years ago, when plants started to grow on the land. This was long before bacterial symbiosis began. The first dinosaurs only appeared around 240 million years ago. Around 100 million years ago, the ancient ancestor plant that first performed symbiosis with bacteria probably borrowed the genes involved in communicating with fungi and used them to communicate with nitrogen-fixing bacteria. Over time, many descendants of this ancestor plant lost the ability to communicate with bacteria but kept the ability to communicate with fungi. 


\section{HOW CAN WE USE THIS KNOWLEDGE TO PROTECT THE PLANET?}

Although modern agriculture provides us with much of the food that we need, researchers have found that agriculture has a negative impact on our planet. The production of fertilizers releases greenhouse gasses, which enhance global warming. But at the same time, fertilizers help us to produce enough plants to satisfy the global demand for food, so we must balance the greenhouse gas emissions with the benefits that fertilizers provide to crops. Nitrogen-fixing bacteria in plant nodules can help us because they provide nitrogen to plants and decrease the need for fertilizers. One way that farmers already make use of this symbiosis is to plant legumes in their fields in rotation with other crops. The legumes naturally increase the amount of nitrogen that is available in the soil. Some researchers are trying to modify the genes of crop plants so they have their own tools to fix nitrogen, without the need for bacteria. Other researchers are trying to understand why many plants lost the ability to form symbiotic relationships with bacteria and whether it is possible to re-introduce this ability into certain crop plants. By harnessing or improving the natural abilities of crop plants to obtain their own nutrients, hopefully we can decrease the negative impacts of agriculture on the environment and so many wild species while still growing enough food to feed the human population.

\section{REFERENCES}

1. Sprent, J. I., Ardley, J., and James, E. K. 2017. Biogeography of nodulated legumes and their nitrogen-fixing symbionts. New Phytol. 215:40-56. doi: $10.1111 /$ nph.14474

2. Pawlowski, K., and Demchenko, K. N. 2012. The diversity of actinorhizal symbiosis. Protoplasma. 249:967-79. doi: 10.1007/s00709-012-0388-4

3. Griesmann, M., Chang, Y., Liu, X., Song, Y., Haberer, G., Crook, M. B., and Roswanjaya, Y. P. 2018. Phylogenomics reveals multiple losses of nitrogen-fixing root nodule symbiosis. Science. 361:eaat1743. doi: 10.1126/science.aat1743

4. Parniske, M. 2008. Arbuscular mycorrhiza: the mother of plant root endosymbioses. Nat Rev Microbiol. 6:763-75. doi: 10.1038/nrmicro1987

SUBMITTED: 29 January 2021; ACCEPTED: 16 December 2021; PUBLISHED ONLINE: 18 January 2022.

EDITED BY: Liesel G. Schneider, The University of Tennessee, Knoxville, United States

CITATION: Berckx F and Pawlowski K (2022) What Are the Small Lumps I See on Some Plant Roots? Front. Young Minds 9:660425. doi: 10.3389/frym.2021.660425

CONFLICT OF INTEREST: The authors declare that the research was conducted in the absence of any commercial or financial relationships that could be construed as a potential conflict of interest. 

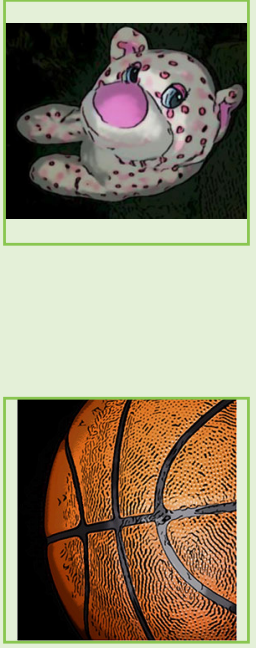

COPYRIGHT (c) 2022 Berckx and Pawlowski. This is an open-access article distributed under the terms of the Creative Commons Attribution License (CC BY). The use, distribution or reproduction in other forums is permitted, provided the original author(s) and the copyright owner(s) are credited and that the original publication in this journal is cited, in accordance with accepted academic practice. No use, distribution or reproduction is permitted which does not comply with these terms.

\section{YOUNG REVIEWERS}

\section{ELLE, AGE: 11}

My name is Elle, and I just turned 12 years old. I love cats, and wish I had one of my own. I love to dance, write, sing, read, and draw. I would like to become a lawyer when I am older. My favorite subjects in school have always been ELA and history. I have participated in the science fair all of my life, and I enjoy watching videos and reading articles to better understand the world around me. Fashion is a passion of mine too.

\section{JACK, AGE: 13}

My name is Jack. I am interested in coding, programming, and cybersecurity. I participate in science and math competitions like Science Olympiad and Math League. I am an avid basketball player. I love to travel and have visited 4 of the 7 continents so far.
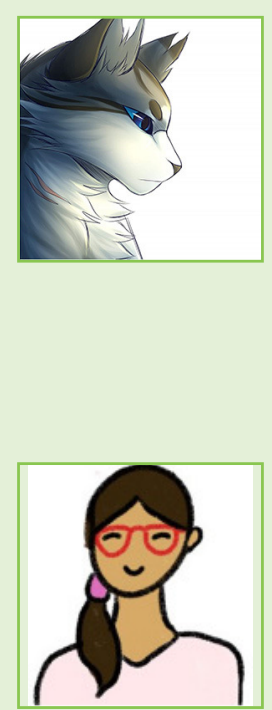

\section{SIRI, AGE: 12}

My name is Siri. I am in the sixth grade. Some things that I enjoy doing are reading, soccer, science, computer science, cooking, and baking. I like to read a series called Warrior Cats, and novels, non-fiction, and scientific novels. I played piano for a few years, but then changed to violin. I love animals and have two dogs and six chickens, and am getting ready to adopt two kittens. I love learning more about animals and plants and have my own succulents. I am trying to learn how to propagate it is clippings.

\section{SOPHIA, AGE: 15}

My name is Sophia. I am on the pre-med pathway in high school. I compete in Science Olympiad, Quiz Bowl, and the Science Fair. I have a love for spelling. I won my school spelling bee multiple years and competed in the Scripps national spelling bee. For relaxation, I enjoy doing art projects and baking culinary treats for my friends and family. I also love to travel. One of my favorite places is Tokyo.

\section{AUTHORS}

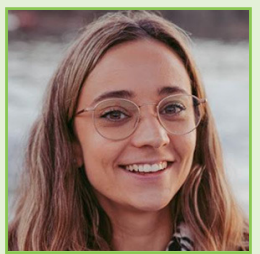

\section{FEDE BERCKX}

Fede is a doctoral candidate at Stockholm University in the lab of Katharina Pawlowski. She received her master's degree in biology at Ghent University in Belgium. She is interested in the interactions between various organisms in their natural environments, with a particular interest in microbial interactions. 
She is passionate about sustainability and issues related to food production and global change. *fede.berckx@asu.se

\section{KATHARINA PAWLOWSKI}

Katharina Pawlowski is a biologist whose work is focused on symbioses between plants and nitrogen-fixing soil bacteria. She is particularly interested in the question of how these symbioses evolved. Katharina studied biology and obtained her doctorate in Germany and worked in Germany, the Netherlands and Sweden. Currently, she is a professor at Stockholm University in Sweden. 